\title{
Pengaruh Dana Desa Terhadap Akumulasi Kapital Di Kabupaten Bondowoso
}

\section{Saiful Amin ${ }^{a}$, Nanda Widaninggar ${ }^{b}$}

${ }^{a}$ Dosen STIE Mandala Jember, saiful@stie-mandala.ac.id

${ }^{b}$ Dosen STIE Mandala Jember, nanda@stie-mandala.ac.id

E-mail Penulis Korespondensi : saiful@stie-mandala.ac.id

\section{N F O A R T I K E L}

Riwayat Artikel:

Dikirim 8 November 2020

Direvisi 10 November 2020

Diterima 15 November 2020

\section{Keywords:}

Dana Desa, Akumulasi Kapital, Pengelolaan

\section{A B S T R A C T}

The Village Fund is a government policy program that aims to achieve equitable development in Indonesia. Since 2015, the use of Village Funds has continued to increase from 20.76 trillion in 2015 to 46.98 trillion in 2016. This study aims to determine the effectiveness of the distribution and use of Village Funds and their impact on increasing capital accumulation in Bondowoso Regency. This research is a quantitative study with a confirmatory approach because the researcher confirms the relationship between the research variables and tests the previously formulated hypothesis. The analytical tool used is Structural Equetion Modeling with the help of Lisrel 8.8 software. Respondents in this study amounted to 60 villages in Bondowoso Regency which were selected based on purposive sampling (to select a district) and simple random sampling (to select a village / respondent). The results of the study stated that the effectiveness of using village funds had a significant effect on increasing capital accumulation for rural communities in Bondowoso Regency. The level of use of village funds which is managed in a transparent, accountable, participatory and responsible manner can increase capital accumulation which includes investment, production, income and savings for rural communities in Bondowoso Regency. 


\section{A B S T R A K}

Dana Desa merupakan salah satu program kebijakan pemerintah yang bertujuan untuk mewujudkan pemerataan pembangunan di Indonesia. Sejak tahun 2015 penggunaan Dana Desa terus meningkat mulai dari 20,76 triliun pada tahun 2015 hingga 46,98 trilliun pada tahun 2016. Penelitian ini bertujuan untuk mengetahui efektivitas penyaluran dan penggunaan Dana Desa serta dampaknya terhadap peningkatan akumulasi kapital di Kabupaten Bondowoso. Penelitian ini merupakan penelitian kuantitatif dengan pendekatan konfirmatori karena peneliti mengkonfirmasi hubungan antara variabel-variabel penelitian dan menguji hipotesis yang dirumuskan sebelumnya. Alat analisis yang digunakan adalah Structural Equetion Modeling dengan bantuan software Lisrel 8.8. Responden dalam penelitian ini berjumlah 60 Desa di Kabupaten Bondowoso yang dipilih berdasarkan Purposive sampling (untuk memilih Kecamatan) dan simple random sampling (untuk memilih Desa/Responden). Hasil Penelitian menyatakan bahwa efektifitas penggunaan dana desa berpengaruh signifikan terhadap peningkatan akumulasi kapital bagi masyarakat desa di Kabupaten Bondowoso.Tingkat penggunaan dana desa yang dikelola secara tranparan, akuntabel, partisipatif dan bertanggung jawab dapat meningkatkan akumlasi capital yang meliputi investasi, produksi, pendapatan dan tabungan bagi masyarakat desa di Kabupaten Bondowoso.

\section{PENDAHULUAN}

Pembangunan ekonomi suatu daerah merupakan suatu kegiatan yang harus dilakukan secara bersama-sama dan berkesinambungan baik dari pemerintah, masyarakat maupun pihak swasta untuk mewujudkan kesejahteraan masyarakat yang adil dan merata. Pembangunan ekonomi dilakukan sebagai langkah untuk mewujudkan pemerataan pembangunan dan pertumbuhan ekonomi suatu daerah menjadi lebih baik. Pertumbuhan ekonomi merupakan salah satu indikator yang sering digunakan dalam mengukur tingkat pembangunan suatu daerah. Adanya pertumbuhan ekonomi suatu daerah dapat tercerminkan melalui adanya perubahan keadaan dan struktur perekonomian yang mengarah pada peningkatan pendapatan masyarakat secara umum. 
Berdasarkan Undang-Undang Nomor 32 Tahun 2004. Suatu daerah diberikan otonomi yang seluas-luasnya untuk mengurus semua penyelenggaraan pemerintah diluar kewenangan pemerintah pusat untuk membuat kebijakan daerah yang berhubungan dengan peningkatan pelayanan dan pemberdayaan masyarakat, serta otonomi yang nyata dan bertanggung jawab. Disentralisasi ini tidak hanya terbatas pada tingkat Kabupaten/Kota tetapi juga Desa sebagai kesatuan masyarakat hukum yang memiliki batas-batas wilayah yang berwenang untuk mengatur dan mengurus kepentingan masyarakat setempat, berdasarkan asal usul dan adat istiadat setempat yang diakui dan dihormati dalam sistem Pemerintahan NKRI (PP Nomor 72 Tahun 2005).

Sebagai konsekwensi atas pemberian suatu kewenangan otonomi terhadap desa dalam mengatur dan mengelola kepentingan masyarakat setempat, maka perlu diatur juga mengenai sumber-sumber pembiayaan untuk mendukung kegiatan tersebut, baik sumber pembiayaan yang berasal dari Pemerintah Kabupaten/Kota; Pemerintah Provinsi; Pemerintah Pusat maupun sumber pembiayaan yang berasal dari Pendapatan Asli Desa. Untuk mendukung hal tersebut diatas, kini bermunculan program-program dari pemerintah pusat maupun pemerintah daerah yang bertujuan untuk mendorong kemampuan masyarakat pedesaan untuk meningkatkan nilai-nilai kearifan lokal dan modal sosial dalam wujud pemberdayaan masyarakat, salah satunya adalah Program Dana Desa yang merupakan wujud dari pemenuhan hak otonomi Desa.Dari tahun ke tahun penggunaan Dana Desa terus meningkat, pada tahun 2015 jumlah dana desa sebesar 20,76 triliun dan meningkat pada tahun 2016 sebesar 46,98 trilliun. Direncanakan program dana desa ini akan terus ditingkatkan untuk mendukung pembangunan di tingkat desa. Agar pelaksanaan Program Dana Desa dapat berjalan dengan efektif, diperlukan pengelolaan anggaran yang bersifat partisipatif, transparan, akuntabel, dan berkelanjutan.

Kabupaten Bondowoso merupakan salah satu Kabupaten di Indonesia yang telah mendapatkan dan menyalurkan Dana Desa. Sejak adanya Program Dana Desa pada tahun 2015, Pemerintah Kabupaten Bondowoso terus mendukung program yang dicanangkan pemerintah pusat dalam mewujudkan pembangunan yang semakin merata hingga ke tingkat Desa. Mengingat besarnya jumlah anggaran yang dikeluarkan pemerintah dalam program penyaluran Dana Desa ini, maka Pemerintah Kabupaten Bondowoso perlu untuk melakukan evaluasi secara berkala tentang efektivitas penyaluran, sistem pengelolaan dan penggunaan Dana Desa agar bisa lebih tepat sasaran. Selain itu, juga perlu dikaji lebih mendalam apakah Dana Desa dapat meningkatkan akumulasi kapital di Desa, serta apakah Dana Desa juga mampu meningkatkan pemberdayaan masyarakat yang bisa dilihat dari tingkat penyerapan tenaga kerja, kesempatan berusaha, peningkatan partisipasi masyarakat dan peningkatan terhadap sarana dan prasarana umum yang dimiliki Desa. Berdasarkan kajian teori dan fenomena di atas, maka peneliti tertarik untuk melakukan penelitian tentang efektivitas penyaluran Dana Desa terhadap peningkatan akumulasi capital dan pemberdayaan masyarakat di Kabupaten Bondowoso. Penelitian ini bertujuan untuk mengetahui faktorfaktor yang mempengaruhi efektivitas penyaluran Dana Desa serta dampaknya terhadap akumulasi capital di Kabupaten Bondowoso.

\section{KAJIAN PUSTAKA}

\section{Penelitian Terdahulu}

Riset yang dilakukan oleh Juniardi dkk (2015) menunjukkan bahwa variabel partisipatif, transparan, akuntabel dan berkelanjutan memiliki pengaruh yang signifikan terhadap variabel efektivitas penyaluran Dana Desa. Dan variabel berkelanjutan memiliki dampak paling dominan terhadap efektivitas penyaluran alokasi dana desa. Untuk mengelola Dana Desa, desa harus mempersiapkan kelembagaan yang terdiri dari tim pelaksana, tim pengawas dan 
tim evaluasi secara khusus. Tim-tim tersebut dibutuhkan agar Dana Desa dapat dikelola dengan baik dan sesuai dengan kepentingan masyarakat. Juniardi dkk (2015).

Dalam praktik pengelolaan keuangan desa sabaiknya melibatkan partisipasi masyarakat untuk mencegah adanya kecurigaan-kecurigaan masyarakat terhadap pengelolaan keuangan desa. Masyarakat desa memahami bahwa akuntansi merupakan instrument akuntabilitas dan transparansi dalam pengelolaan keuangan desa. Ayu Komang dkk (2014).

Riset yang dilakukan oleh Mahfud, 2012 menyatakan bahwa sebagian besar penggunaan Dana Desa lebih banyak diarahkan pada kegiatan fisik (pembangunan sarana dan prasarana fisiki) disusul kemudian untuk kesejahteraan perangkat desa. Sedangkan untuk prosentase penggunaan Dana Desa untuk lembaga masyarakat besarannya tidak sesuai dengan aturan yang ada. Penelitian lain menyebutkan bahwa Alokasi Dana Desa memiliki dampak positif dan efek yang signifikan terhadap penyerapan tenaga kerja, perbaikan infrastruktur public, peningkatan pengetahuan masyarakat dan peningkatan partisipasi masyarakat dalam pembangunan Desa (Riska, 2012).

\section{Pemerintahan Desa}

Pemerintahan Desa menurut Prof. Drs. HAW. Widjaja dalam bukunya "Otonomi Desa" Pemerintahan Desa diartikan sebagai: "Penyelenggaraan Pemerintahan Desa merupakan Subsistem dari sistem penyelenggaraan Pemerintah, sehingga Desa memiliki kewenangan untuk mengatur dan mengurus kepentingan masyarakatnya. Kepala Desa bertanggung jawab kepada Badan Permusyawaratan Desa dan menyampaikan laporan pelaksanaan tersebut kepada Bupati”. (Widjaja, 2003: 3).

\section{Dana Desa dan Keuangan Desa}

Berdasarkan penjelasan pasal 72 huruf b UU No 6/2014 Dana Desa adalah dana yang bersumber dari APBN, yang ditransfer melalui APBD Kabupaten/Kota yang digunakan untuk mendanai kegiatan pembangunan desa, pemberdayaan, pemerintahan desa dan kemasyarakatan. Meskipun Desa mempunyai hak untuk mengelola kewenangannya, namun demikian desa tetap merupakan bagian dari Kabupaten/Kota dan bukan merupakan daerah otonom tersendiri. Dana Desa diprioritaskan untuk membiayai pembangunan dan pemberdayaan masyarakat yang

pelaksanaannya diutamakan secara swakelola dengan menggunakan sumber daya/bahan baku local, dan diupayakan dengan lebih banyak menyerap tenaga kerja dari masyarakat desa setempat. (Pasal 25 PMK 247)

\section{Akumulasi Kapital}

Menurut Marx, syarat pertama akumulasi kapital adalah pada rencana kapitalis untuk menjual komoditasnya dan mengubah kembali bagian terbesar dari uang yang diterimanya untuk menjadi kapital. Deskripsi Marx tentang proses akumulasi kapital ini, menurut Turner (1981), berasal dari sifat nilai lebih, yakni: Pertama, reproduksi sederhana yang fokus pada cara keberlanjutan hubungan sosial kapitalis yang diciptakan ulang oleh buruh upahan. Kedua, konversi dari nilai lebih ke dalam kapital, yang fokus pada cara dimana nilai lebih digunakan untuk mengakumulasi kapital.

\section{Pemberdayaan Masyarakat}

Pemberdayaan masyarakat menurut Sumaryadi (2005, h.25) tujuan pemberdayaan masyarakat pada dasarnya adalah membantu pengembangan manusiawi yang otentik dan integral dari masyarakat yang lemah, miskin, marjinal dan kaum kecil dan memberdayakan kelompok-kelompok masyarakat tersebut secara sosio ekonomis sehingga mereka dapat lebih mandiri dan dapat memenuhi kebutuhan dasar hidup mereka, namun sanggup berperan serta 
dalam pengembangan masyarakat. Indikator pemberdayaan masyarakat adalah kesempatan kerja, kesempatan usaha, peningkatan partisipasi masyarakat, dan peningkatan sarana dan prasarana publik.

\section{Definisi Operasional Variabel}

Dana Desa adalah dana yang bersumber dari APBN, yang ditransfer melalui APBD Kabupaten/Kota yang digunakan untuk mendanai kegiatan pembangunan desa, pemberdayaan, pemerintahan desa dan kemasyarakatan. Efektivitas penyaluran Dana Desa diukur dengan aspek partisipatif, transparan, akuntabel dan berkelanjutan.Akumulasi Kapital merupakan Penggunaan nilai lebih sebagai kapital atau pengubahan kembali nilai lebih menjadi capital. Indikator dari Akumulasi kapital adalah Investasi, produksi, pendapatan, dan tabungan.

\section{METODE PENELITIAN}

Penelitian ini merupakan penelitian explanatory dengan pendekatan kuantitatif. Lokasi penelitian berada di Bondowoso dengan populasi adalah seluruh pemerintah desa yang ada di Kabupaten Bondowoso. Metode pengambilan sampel menggunakan Doeble Sampli (Purposive Sampling dan Simple Random Sampling). sampel dalam penelitian ini berjumlah 60 responden. Jumlah sampel diperoleh dari seluruh indikator variabel yang digunakan dalam penelitian ini yaitu 12 subindikator dikalikan dengan 5.(Malhotra, 2005).

Analisis data dalam penelitian ini menggunakan analisis regresi linier berganda dengan variabel laten. menggunakan software Lisrel 8.8. Menurut Maruyama (1998) dalam Wijaya (2009) menyebutkan bahwa analisis regresi linier berganda dengan variabel laten merupakan sebuah model statistik yang memberikan perkiraan perhitungan dari kekuatan hubugan hipotesis antara variabel dalam sebuah model teoritis, baik secara langsung atau melalui variabel antara (Intervening or moderating).

\section{Uji Validitas dan ReliabilitasVariabel Evektivitas Dana Desa}

Tabel 2. Hasil Uji Validitas dan ReliabilitasEvektivitas Dana Desa

\begin{tabular}{|c|c|c|c|r|}
\hline Indicator & $\begin{array}{c}\text { Standardized } \\
\text { Solution/Factor } \\
\text { Loading }\end{array}$ & Error Variance & T-Value & Mean Score \\
\hline $\mathrm{X} 1.1$ & 0,75 & 0,22 & 7,27 & 1,96 \\
\hline $\mathrm{X} 1.2$ & 0,90 & 0,08 & 4,51 & 1,96 \\
\hline $\mathrm{X} 1.3$ & 0,82 & 0,15 & 6,51 & 1,96 \\
\hline $\mathrm{X} 1.4$ & 0,52 & 0,57 & 8,14 & 1,96 \\
\hline
\end{tabular}

Tabel diatas menunjukkan bahwa semua indikator memiliki t-value lebih besar dari 1.96 (95\% tingkat kepercayaan). Selain itu semua indikator pembentuk konstrukEfektifitas Dana Desa memiliki nilai Loading factor lebih besar dari 0.50. Sehingga dapat disimpulkan bahwa semua indikator secara signifikan berhubungan dengan konstruk efektivitas dana desa atau semua indikator dapat dinyatakan valid.

ConstructreliabilityEfektifitas Dana Desasebesar 1.03 berada diatas nilai yang direkomendasikan 0,60. Dengan demikian semua indikator pembentuk konstruk Efektifitas Dana Desa adalah reliable. 
Jurnal Manajemen Bisnis dan Manajemen Keuangan, Volume 1 No. 1 November 2020

\section{Uji Validitas dan ReliabilitasVariabel Akumulasi Kapital}

Tabel 3. Hasil Uji Validitas dan Reliabilitas Evektivitas Dana Desa

\begin{tabular}{|c|c|c|c|c|}
\hline Indicator & $\begin{array}{c}\text { Standardized Solution / } \\
\text { Loading Factor }\end{array}$ & Error Variance & T-Value & Mean Score \\
\hline Y1.1 & 0,50 & 0,39 & 5,07 & 3,92 \\
\hline Y1.2 & 0,59 & 0,45 & 5,29 & 3,92 \\
\hline Y1.3 & 0,58 & 0,31 & 5,11 & 89 \\
\hline Y1.4 & 0,73 & 0,22 & 5,47 & 3,78 \\
\hline
\end{tabular}

Tabel Diatas menunjukkan bahwa seluruh indikator memiliki t-value $>1,96$ (tingkat kepercayaan 95\%). Selain itu semua indikator pembentuk konstruk akumulasi kapital memiliki nilai Loading Faktor lebih besar dari 0,50. Sehingga dapat disimpulkan bahwa semua indikator secara signifikan berhubungan dengan konstruk akumulasi kapitalatau semua indikator dapat dinyatakan valid. Construct reliability akumulasi kapitalsebesar 1,00 berada diatas nilai yang direkomendasikan 0,60. Dengan demikiansemua indikator pembentuk konstruk akumulasi kapitaladalah reliable.

\section{a. Uji Hipotesis}

Berdasarkan hasil analisis regresi linier berganda dengan variabel laten, maka selanjutnya dilakukan uji hipotesis penelitian pada model persamaan yang bisa dilihat pada tebel berikut:

Tabel 4. Uji Hipotesis

\begin{tabular}{|c|c|c|c|c|}
\hline $\begin{array}{c}\text { Hypothe } \\
\text { sis }\end{array}$ & Standardized solution & T-value & T-Table & Specification \\
\hline H1 & 0,62 & 1,98 & 1,96 & Diterima \\
\hline
\end{tabular}

Berdasarkan Tabel uji hipotesis diatas, dapat dilihat bahwaT-Value memiliki nilai sebesar 1,98 lebih besar dari nilai T-Tabel $(1,96)$ dengan Loading factor sebesar 0,62. Hasil ini menunjukkan bahwa efektivitas dana desa berpengaruh signifikan terhadap akumulasi kapital. Hal ini berarti tingkat penggunaan dana desa yang dikelola secara tranparan, akuntabel, partisipatif dan bertanggung jawab dapat meningkatkan akumlasi capital yang meliputi investasi, produksi, pendapatan dan tabungan bagi masyarakat desa di Kabupaten Bondowoso.

\section{PEMBAHASAN}

Hubungan antara efektifitas dana desa terhadap akumulasi kapital dinyatakan memiliki pengaruh signifikan.Hal ini berarti tingkat penggunaan dana desa yang dikelola secara tranparan, akuntabel, partisipatif dan bertanggung jawab dapat meningkatkan terciptanya akumulasi Kapital di desa. Akumulasi Kapital merupakan Penggunaan nilai lebih sebagai kapital atau pengubahan kembali nilai lebih menjadi kapital. Akumulasi kapital yang dimaksud meliputi Investasi, produksi, pendapatan, dan tabungan.

Hasil penelitian ini sejalan dengan penelitian yang telah dilakukan oleh Juniardi dkk (2015) yang menyatakan bahwa variabel partisipatif, transparan, akuntabel dan berkelanjutan memiliki pengaruh yang signifikan terhadap variabel efektivitas penyaluran Dana Desa. Hasil 
ini juga sejalan dengan penelitian yang dilakukan oleh Mahfud, 2012 menyatakan bahwa sebagian besar penggunaan Dana Desa lebih banyak diarahkan pada kegiatan fisik (pembangunan sarana dan prasarana fisiki) disusul kemudian untuk kesejahteraan perangkat desa. Sedangkan untuk prosentase penggunaan Dana Desa untuk lembaga masyarakat besarannya tidak sesuai dengan aturan yang ada. Selain itu hasil ini juga mendukung hasil penelitian(Riska, 2012). Yang menyebutkan bahwa Alokasi Dana Desa memiliki dampak positif dan efek yang signifikan terhadap penyerapan tenaga kerja, perbaikan infrastruktur public, peningkatan pengetahuan masyarakat dan peningkatan partisipasi masyarakat dalam pembangunan Desa.

Sesuai hasil penelitian diatas dapat dikatakan bahwa penggunaan dana desa secara tepat guna dapat meningkatkan akumulasi kapital, yaitu peningkatan terhadap investasi, produksi, pendapatan dan tabungan. Menurut Marx, syarat pertama akumulasi kapital adalah pada rencana kapitalis untuk menjual komoditasnya dan mengubah kembali bagian terbesar dari uang yang diterimanya untuk menjadi kapital.Dalam mendukung pertumbuhan ekonomi di Indonesia pada umumnya dan di daerah pada khususnya, diperlukan adanya pemerataan pembangunan dan kesejahteraan masyarakat antar daerah.Untuk mengurangi kesenjangan antar wilayah, memerlukan peningkatan pertumbuhan ekonomi yang mampu menciptakan 'akumulasi kapital' di masyarakat yang bisa didapat dari siklus investasi, produksi, pendapatan, konsumsi, tabungan, re-investasi yang membumbung. Selain itu, Dalam praktik pengelolaan keuangan desa sabaiknya melibatkan partisipasi masyarakat untuk mencegah adanya kecurigaan-kecurigaan masyarakat terhadap pengelolaan keuangan desa. Masyarakat desa memahami bahwa akuntansi merupakan instrument akuntabilitas dan transparansi dalam pengelolaan keuangan desa.

\section{SIMPULAN}

Berdasarkan hasil analisis statistik dalam penelitian ini, maka dapat disimpulkan bahwaefektifitas dana desa terhadap akumulasi kapital memiliki pengaruh signifikan terhadap akumulasi capital. Hal ini berarti tingkat penggunaan dana desa yang dikelola secara tranparan, akuntabel, partisipatif dan bertanggung jawab dapat meningkatkan akumlasi capital yang meliputi investasi, produksi, pendapatan dan tabungan bagi masyarakat desa di Kabupaten Bondowoso.

\section{DAFTAR PUSTAKA}

Anderson, James, C. \& Gerbing, David, W. Structural Equation Modeling in Practice: A Review and Recommended Two-Step Approach. Psychological Bulletin 1998, Vol 103, No.3 411-423.

Dian Srirezeki, 2009, Aplikasi Struktural Equation Modeling Pada Tesis, Tutorial

Jurniadi dkk, 2015, Faktor-Faktor Yang Berpengaruh Terhadap Efektivitas Penyaluran Alokasi Dana Desa Di Kecamatan Teluk Pandan Kabupaten Kutai Timur, ejournal administrative reform, Vol 1 No 1 2015: 112-124, ISSN 2338-7637. 
Komang A, dkk, 2014, Membedah Akuntabilitas Praktik Pengelolaan Keuangan Desa Pakraman Kubutambahan-Bali, e-Journal S1 Ak Universitas Pendidikan Ganesha, Singaraja.

Mahfud, 2012, Analisis Dampak Alokasi Dana Desa (ADD) Terhadap Pemberdayaan Masyarakat dan Kelembagaan Desa, Jurnal, Undip Semarang.

Malhotra, M.K 2012, Operation Management, $10^{\text {th }}$ Edition, USA: Pearson

Marx, Karl, (terjemahan), 2004, Das Kapital Kritik der poltischen Oekonomie, diterjemahkan oleh Oey Hay Djoen dalam buku 'Kapital, Sebuah Kritik Ekonomi Politik dalam Buku I, II, III', Penerbit Ultimus, Bandung.

Nurliana, 2013, Pengelolaan Alokasi Dana Desa (ADD) Dalam Pembangunan Fisik Di Desa Sukomulyo Kecamatan Sepaku Kabupaten Penajam Paser Utara, Jurnal, eJournal Administrasi Negara, 1(3) 2013 : 1059-1070 ISSN 0000-0000, Universitas Mulawarman.

Republik Indonesia, 2004, UU Nomor 32 Tahun 2004 tentang "Pemerintah Daerah. Jakarta

Republik Indonesia, 2005, PP Nomor 72 tahun 2005, Sistem Pemerintahan Negara Kesatuan Republik Indonesia. Jakarta

Republik Indonesia, 2007, Peraturan Menteri Dalam Negeri Nomor 37 Tahun 2007 tentang Pedoman Pengelolaan Keuangan Desa. Jakarta

Republik Indonesia, 2016, Kebijakan Dana Desa TA 2016, Direktorat Jenderal Perimbangan Keuangan RI, Kementerian Keuangan Republik Indonesia.

Sugiyono, (2010) Metode Penelitian Bisnis, Bandung : Alfabeta.

Times Indonesia, Kabupaten Bondowoso Kembali Mendapat Opini WTP dari BPKhttp://www.timesindonesia.co.id/read/148985/20170526/171447/kabupatenbondowoso-kembali-mendapat-opini-wtp-dari-bpk/ diakses pada 1 April 2017.

Wijaya, Toni. 2009, “Analisis Structural Equation Modeling Menggunakan AMOS" Yogyakarta: Universitas Atmajaya.

Yuliani, 2012, Analisis Dampak Alokasi Dana Desa (ADD) Terhadap Pemberdayaan Masyarakat dan Kelembagaan Desa di Kabupaten Boyolali, Skripsi, Fakultas Ekonomi Universitas Muhammadiyah, Surakarta. 